\title{
The lack of males due to illegal trapping is causing polygyny in the globally endangered Yellow Cardinal Gubernatrix cristata
}

\author{
Luciano N. Segura ${ }^{1,4}$, Milton Perelló ${ }^{2,3}$, Néstor H. Gress ${ }^{3}$ \& Rafael Ontiveros ${ }^{3}$ \\ - Sección Ornitología, Museo de La Plata, Universidad Nacional de La Plata, La Plata, Buenos Aires, Argentina. \\ Fundación Azara, Departamento de Ciencias Naturales y Antropológicas, Universidad Maimónides, Ciudad Autónoma de Buenos Aires, Buenos \\ Aires, Argentina. \\ 3 COA Valle de Conesa, General Conesa, Río Negro, Argentina. \\ 4 Corresponding author: luchosegura79@gmail.com
}

Received on 24 October 2018. Accepted on 11 March 2019.

\begin{abstract}
We present breeding data from the southernmost populations of the globally "Endangered" Yellow Cardinal Gubernatrix cristata in Argentina, confirming the presence of current breeding populations in the region. We monitored a family group in a nesting territory composed of one male and three females throughout the breeding season 2017-2018. We found a low nest success and productivity, probably associated with the lower contribution of the male, since it was attending three reproductive females simultaneously. We attribute this uncommon case of polygyny to the lack of males in the area caused by the high intensity of male trapping for illegal trade.
\end{abstract}

KEY-WORDS: breeding biology, cage birds, Monte ecoregion, Neotropical birds, threatened species.

\section{INTRODUCTION}

The Yellow Cardinal Gubernatrix cristata is a Neotropical threatened passerine from the southern cone of South America (Ridgely \& Tudor 2009). It is a territorial and socially monogamous species, where mated pairs usually stay together for more than one breeding season (Domínguez et al. 2015a, Beier et al. 2017). In the past, this species was widely distributed in thorny deciduous shrubland forests of central Argentina, most of Uruguay and part of southern Brazil (Jaramillo 2019). Due to their colour and song, they have been captured for illegal trade in wildlife (mainly the males) and, along with habitat loss, were the main causes of the great population decline and fragmentation for this species (Domínguez et al. 2017), now considered as globally "Endangered" and regionally "Threatened" (estimated total population: 1500-3000 individuals; BirdLife International 2018).

Social polygyny, where one male mates with more than one female while each female mates with only one male, is thought to be the fundamental mating system of animals (Bennett \& Owens 2002). Under certain circumstances, polygyny among birds may occur when males hold valuable resources, such as high-quality territories, and then females tend to choose superior males (Orians 1969). But most birds, however, are monogamous because apparently both parents must help to rear the young if the adults are to have much chance of leaving any genes to posterity (Bennett \& Owens 2002). In this contribution we present novel information about an uncommon case of polygyny in this socially monogamous cardinal. In addition, we present breeding data from a family group composed of one male and three females throughout the entire breeding season 20172018.

\section{METHODS}

The study was conducted in a private farm located northeast of General Conesa, eastern Río Negro province, Argentina (39 $55^{\circ} 12.32^{\prime \prime}$; $64^{\circ} 16^{\prime} 29.14^{\prime \prime}$ W; Fig. 1). From the National Road 251 (distant $12 \mathrm{~km}$ straight line), the access to the study site does not present any restrictions, which is why the area has been used for illegal trapping in recent decades. At present, although the access is still free, the farm-owners chase away the trappers preventing captures in this area. The study area is representative of the Monte ecoregion (Brown et al. 2006), with large areas of native xerophytic vegetation altered by extensive and low-density cattle grazing. This region is characterized by warm summers (maximum temperature: $42.3^{\circ} \mathrm{C}$ ) and 
cold winters (minimum temperature: $-13.5^{\circ} \mathrm{C}$ ), with most precipitations occurring between November-March. The National Meteorological Survey of Argentina from 1985 to 2015 reports mean annual rainfall as $259 \mathrm{~mm}$ and mean annual temperature as $15^{\circ} \mathrm{C}$.

Following the comment of a local birdwatcher during September 2017 (prior to the start of the breeding season), we detected a family group composed of one male and three females of the threatened cardinal. We then carried out observations in that breeding area during the entire breeding season, from October 2017 to January 2018. The nests were found by systematically searching in potential nest sites and observing the behaviour of territorial breeders. We georeferenced each nest location (Garmin GPS) and we visited nests every 10-15 days during the nesting cycle. We monitored the nests until nestlings fledged or the nest failed. Close to the fledging date, we inspected nests from a distance of $2-4 \mathrm{~m}$ to minimize the risk of premature fledging. At each visit, we avoid manipulating the nest content (eggs or nestlings) to avoid disturbances that influence reproductive success.

We considered a nest successful when at least one nestling left the nest. We considered a nest predated if clutch disappeared between two consecutive visits or when the chicks disappeared from their nests before they were old enough to fledge and no parental activity was detected near the nest (see Segura \& Reboreda 2012). None of the monitored nests was abandoned. As individuals were unmarked, we identified each breeder by field observations of unique marks on plumage (mainly in females) and also on the dates of start and end of each breeding attempt. Productivity was calculated as the mean number of fledglings by successful nests. We calculated the apparent nest success as the ratio between the number of successful nests and all monitored nests (Segura et al. 2015). We delimited the breeding territory as the maximum area that the male defended, where it nested and where the family group was observed feeding (see Beier et al. 2017). To locate the territory and nests in a map, we used an image from Google Earth (02 January 2018).

\section{RESULTS}

During the entire breeding season, we found a nesting territory with three females and only one male. During visits, while we were moving from one nest to another, the lonely male accompanied us and defended each of the nests from where one of the three females flushed. We found a total of eight nests (two for one female, two for another and four for another). One nest was found under
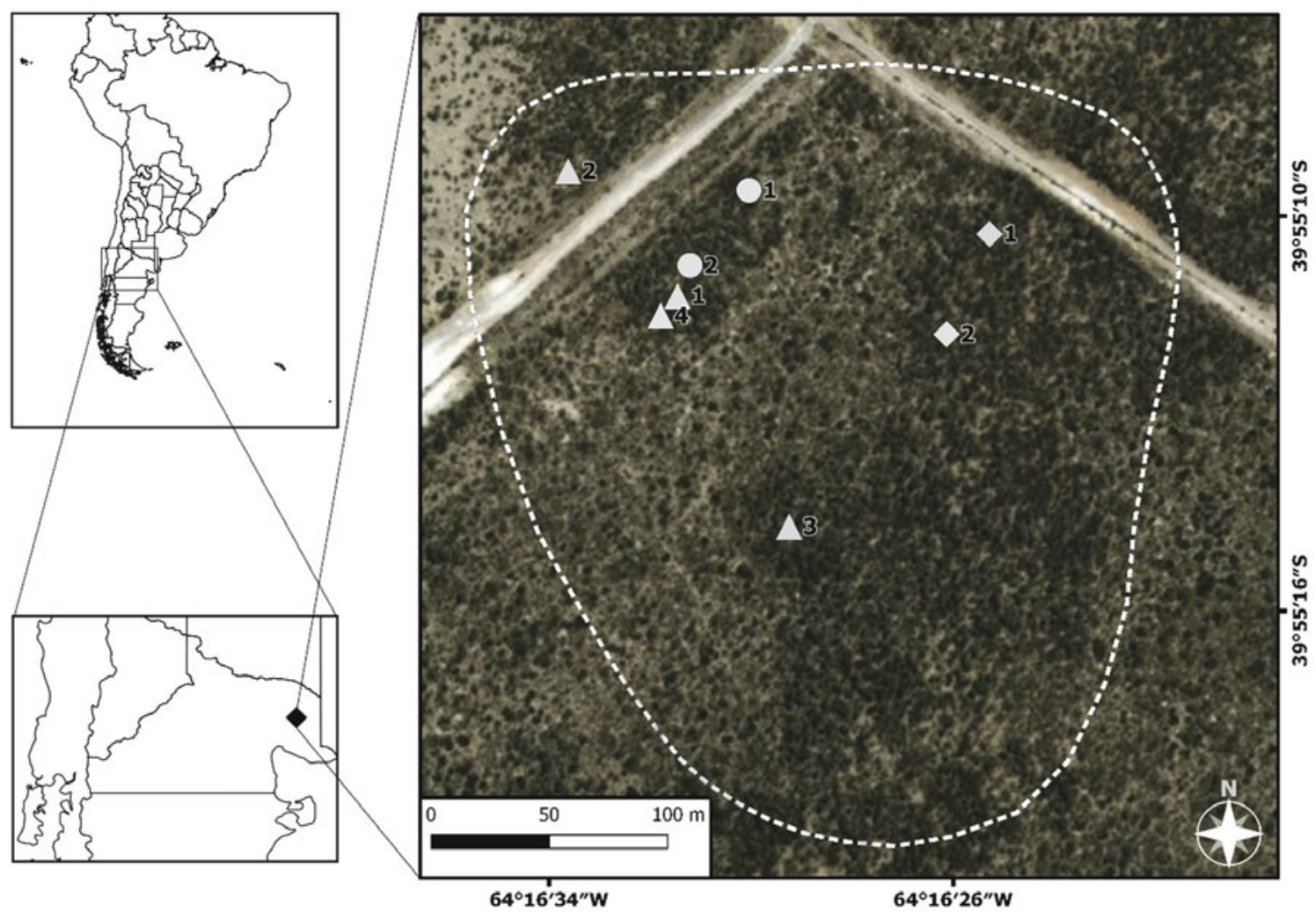

Figure 1. Map showing the location of the study site in southern Argentina, with indication of the breeding territory (dashed line) defended by the Yellow Cardinal male and his three females. Geometric figures (diamonds, triangles and circles) indicate the different females, while numbers indicate the order of each female breeding attempt throughout the breeding season 2017-2018. 
construction and the remaining ones during incubation. By backdating from hatching dates, the first evidence of nest initiation was on 02 October (considering 13 days of incubation; Domínguez et al. 2015a, Beier \& Fontana 2019) and the latest evidence of nest activity was a predated nest on 19 January, thus giving a breeding season length of 108 days. Breeding territory size was $\sim 9$ ha (Fig. 1), including movements of the entire family group.

The nest was a semi-spherical cup of $\sim 15 \mathrm{~cm}$ external diameter with an external layer of twigs with thorns, and an internal layer of finer branches, horse hair, compacted grass material grass and seeds (Fig. 2). All nests were built in Chañar Tree (Geoffroea decorticans) and were located in main branches close to the center of the tree crown, never in the periphery. Mean clutch size was $3.12 \pm 0.12$ eggs (range $=3-4, n=8$ nests). Eggs were ovoid, bluish-green background colour with black spots more concentrated on the wider end of the egg. Mean number of hatchlings per nest was $2.75 \pm 0.25$ (range $=2-3, n=4$ nests) and nest productivity was one fledgling per successful nest $(n$ $=2$ nests). We did not detect partial egg loss, but partial brood losses were detected in the two nests that reached the fledging stage (in one nest the reduction was from three chicks to one, and in the other from two to one). Of the eight monitored nests, two $(25 \%)$ were successful and six $(75 \%)$ were predated (four during incubation and two during the nestling stage). We did not observe nest helpers, nor Shiny Cowbird (Molothrus bonariensis) brood parasitism, as well as any agonistic interactions with other conspecifics in the area.

\section{DISCUSSION}

We present relevant breeding data from Argentinean populations of the Yellow Cardinal, confirming the presence of current breeding populations in the southern limit distribution for this globally "Endangered" species.

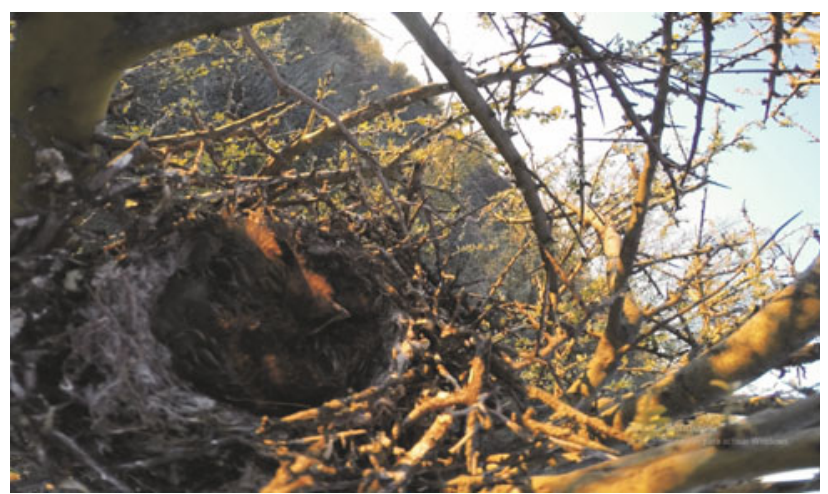

Figure 2. Yellow Cardinal nest with three nestlings observed on 11 November 2017 in a private farm located northeast of General Conesa, eastern Río Negro province, Argentina. Photo author: M. Perelló.
This contribution adds to the few existing breeding studies on the species (Domínguez et al. 2015a \& b, de la Peña 2016, Beier et al. 2017, Beier \& Fontana 2019), finding a new problem for the species caused by the low proportion of males (see Pessino \& Tittarelli 2006) that may force them to incur a polygynous system in which they have less reproductive success. These results mean that greater control by government authorities to prevent illegal trapping is essential and must be implemented soon.

For these latitudes, the only nesting record for the species dates from 1995 (compiled by de la Peña 2016), where an active nest with three eggs in November was report. Unlike what has been recently published for the species (Beier et al. 2017, Beier \& Fontana 2019), we did not observe breeding attempts with helpers contributing on the nest defence or the nestling/fledgling provisioning. Similarly, although Shiny Cowbirds are common in the area (L. Segura, pers. obs.), we did not observe brood parasitism in nests (Domínguez et al. 2015a, Beier \& Fontana 2019). We found that 25\% of the nests were successful, which is similar to that found by Beier \& Fontana (2019), but less than the $-40 \%$ found by Domínguez et al. (2015a) or $-50 \%$ by Beier et al. (2017) for the northern populations of the species. Nest productivity found (only one fledgling per successful nest) was also lower than the 1.6 fledglings per successful nest reported by Domínguez et al. (2015a), Beier et al. (2017) and Beier \& Fontana (2019). In the same sense, partial brood loss detected was higher than reported by Domínguez et al. (2015a). As we did not manipulate nestlings, we are unable to determine if brood reduction was caused by starvation. Both the low apparent nest success as well as the low nest productivity (Domínguez et al. 2015a, Beier et al. 2017, Beier \& Fontana 2019) could be associated with the lower contribution of the male in this socially monogamous species (i.e., by reducing the nest defence or the food delivery to the nestlings; Bennett \& Owens 2002) since it was attending three active reproductive females simultaneously.

As regards the case of polygyny we are reporting, we are confident that the origin of this uncommon behaviour (considering that the species is typically socially monogamous) is the lack of males in the area, caused directly by the high intensity of male trapping for illegal trade (Collar et al. 1992, Pessino \& Tittarelli 2006, Bertonatti 2017, SAyDS 2017). Based on farm-owners' comments and local birdwatchers' sightings records (COA Valle de Conesa, unpub. data), captures for illegal trade in the area was severe in the last decades. Then, when females outnumber males, at least shortly in a given breeding area, it is expected that certain breeding anomalies begin to appear (Engen et al. 2003). In addition to our case of polygyny, another phenomenon for southern populations 
of the cardinal is the presence of hybrids between females Yellow Cardinal and males of the Common Diuca-Finch Diuca diuca (BirdLife International 2018), which has been also associated to the lack of males in the breeding areas (Bertonatti \& López-Guerra 1997). In addition to our finding, there are some recent records in the area from online databases, such as eBird (https://ebird.org/), or the "Censo Nacional de Cardenal Amarillo" (https://www. avesargentinas.org.ar)" that evidence that the species is still present in the area and that conservation actions must be taken immediately. As the southern populations of the cardinal are genetically isolated (Domínguez et al. 2017) and have very few natural protected areas (Brown et al. 2006) that ensure adequate nesting habitat for the species, we strongly recommend that government authorities take urgent measures to ensure the conservation of these breeding populations.

\section{ACKNOWLEDGEMENTS}

We are grateful to B. Mahler for helpful comments to a previous version of this manuscript, $M$. Colombo for help with figures and Virginia Lynch for help in data collection. This work was supported by the "Fondo para la Investigación Cientifica y Tecnológica" (FONCyT, ANPCyT) under grant PICT \#2014-3347. L.N.S. is a CONICET Research Fellow.

\section{REFERENCES}

Beier C. \& Fontana C.S. 2019. Breeding biology of the endangered Yellow Cardinal Gubernatrix cristata in Brazil. Revista Brasileira de Ornitologia 27: 44-52.

Beier C., Repenning M., Silveira-Pereira M., Pereira A. \& Fontana C.S. 2017. Cooperative breeding and demography of Yellow Cardinal Gubernatrix cristata in Brazil. Revista Brasileira de Ornitologia 25: 12-19.

Bennett P.M. \& Owens I.P.F. 2002. Evolutionary ecology of birds: life histories, mating systems and extinction. Oxford: Oxford University Press.

Bertonatti C. 2017. Un muestreo del tráfico de especies en la Argentina durante el año 2016. Buenos Aires: Azara Fundación de Historia Natural. http://fundacionazara.org.ar/img/otras-publicaciones/ Bertonatti-2017-Un-muestreo-del-trafico-de-especies-en-laArgentina-durante-el-2016.pdf (Access on 21 April 2019).
Bertonatti C. \& Lopez-Guerra A. 1997. Hibridación entre Cardenal Amarillo (Gubernatrix cristata) y Diuca Comun (Diuca diuca minor) en estado silvestre en la Argentina. Hornero 14: 235-242.

BirdLife International. 2018. Species factsheet: Gubernatrix cristata. http://datazone.birdlife.org/species/factsheet/yellow-cardinalgubernatrix-cristata (Access on 11 September 2018).

Brown A., Martinez-Ortiz U., Acerbi M. \& Corcuera J. 2006. Situación ambiental argentina. Buenos Aires: Fundación Vida Silvestre Argentina.

Collar N.J., Gonzaga L.P., Krabbe N., Madroño-Nieto A., Naranjo L.G., Parker-III T. A. \& Wege D.C. 1992. Threatened birds of the Americas: the ICBP/IUCN red data book. Cambridge: International Council for Bird Preservation.

de la Peña M.R. 2016. Aves argentinas: descripción, comportamiento, reproducción y distribución: Mimidae a Passeridae. Comunicaciones del Museo Provincial de Ciencias Naturales Florentino Ameghino 21: $1-564$.

Domínguez M., Reboreda J.C. \& Mahler B. 2015a. Impact of Shiny Cowbird and botfly parasitism on the reproductive success of the globally endangered Yellow Cardinal Gubernatrix cristata. Bird Conservation International 25: 294-305.

Domínguez M., Ayarragaray M. \& Lapido R. 2015b. Nidos de Cardenal Amarillo (Gubernatrix cristata) en la provincia de San Luis, Argentina. Nuestras Aves 60: 8-10.

Domínguez M., Tiedemann R., Reboreda J.C., Segura L., Tittarelli F. \& Mahler B. 2017. Genetic structure reveals management units for the Yellow Cardinal (Gubernatrix cristata), endangered by habitat loss and illegal trapping. Conservation Genetics 18: $1131-1140$

Engen S., Lande R. \& Sæther B.E. 2003. Demographic stochasticity and Allee effects in populations with two sexes. Ecology 84: 2378-2386.

Jaramillo A. 2019. Yellow Cardinal. In: del Hoyo J., Elliot A., Sargatal J., Christie D.A. \& de Juana E. (eds.). Handbook of birds of the world alive. Barcelona: Lynx Editions. https://www.hbw.com/ node/62098 (Access on 22 April 2019).

Orians G.H. 1969. On the evolution of mating systems in birds and mammals. American Naturalist 103: 589-603.

Pessino M. \& Tittarelli R.F. 2006. The Yellow Cardinal (Gubernatrix cristata): a diagnosis of its situation in the province of La Pampa, Argentina. Gestion Ambiental 12: 69-76.

Ridgely R.S. \& Tudor G. 2009. Field guide to the songbirds of South America: the passerines. Austin: University of Texas Press.

SAyDS [Secretaría de Ambiente y Desarrollo Sustentable de la Nación]. 2017. Banco de registros del Cardenal Amarillo. Buenos Aires: Dirección de Fauna Silvestre y Conservación de la Biodiversidad.

Segura L.N., Mahler B., Berkunsky I. \& Reboreda J.C. 2015. Nesting biology of the Red-crested Cardinal (Paroaria coronata) in south temperate forests of central Argentina. Wilson Journal of Ornithology 127: 249-258.

Segura L.N. \& Reboreda J.C. 2012. Nest survival rates of Red-crested Cardinals increase with nest age in south-temperate forests of Argentina. Journal of Field Ornithology 83: 343-350.

Associate Editor: Carla S. Fontana. 